\title{
Short communication: Supplementing grape marc to cows fed a pasture-based diet as a method to alter nitrogen partitioning and excretion
}

\author{
S. L. Greenwood, ${ }^{\star 1}$ G. R. Edwards, ${ }^{*}$ and R. Harrison† \\ ${ }^{*}$ Department of Agricultural Sciences, and \\ †Department of Wine, Food and Molecular Biosciences, Lincoln University, Lincoln 7647, New Zealand
}

\begin{abstract}
The inclusion of the grape marc into livestock rations provides an opportunity not only to use a waste byproduct resourcefully, but also to induce beneficial metabolic changes in animals. Grape marc contains condensed tannins that could alter $\mathrm{N}$ metabolism, which would be beneficial from an environmental perspective. The objective was to determine if dietary grape marc could decrease urinary $\mathrm{N}$ excretion from nonlactating dairy cattle. Eighteen multiparous cows were randomly divided into 2 equal groups, receiving either (1) pasture $+2 \mathrm{~kg}$ of dry matter $(\mathrm{DM}) / \mathrm{d}$ energy pellet per cow (control group) or (2) pasture $+2 \mathrm{~kg}$ of DM/d energy pellet per cow $+3 \mathrm{~kg}$ of $\mathrm{DM} / \mathrm{d}$ grape marc per cow. Urine, fecal, and blood samples were collected at baseline ( $\mathrm{d} 0$ ) and at $\mathrm{d} 9$. Cows receiving grape marc excreted $22 \%$ more $\mathrm{N}$ in feces compared with the control group. Cows offered grape marc had lower plasma urea nitrogen concentrations (2.42 and $2.97 \pm 0.1 \mathrm{mmol} / \mathrm{L}$ from treatment and control cows, respectively), but had no significant difference in urine urea concentration compared with control animals (84.24 and $114.1 \pm 17.62 \mathrm{mmol} / \mathrm{L}$ from treatment and control cows, respectively). Overall, the potential exists to alter $\mathrm{N}$ metabolism in dairy cows using dietary grape marc. The exact mechanisms causing this shift in $\mathrm{N}$ metabolism require further investigation.
\end{abstract}

Key words: grape marc, dairy cattle, nitrogen metabolism, supplement

\section{Short Communication}

Environmental protection is of concern for New Zealand ruminant production systems, as public interest in climate change, methane emissions, and nitrogen leaching is increasing. Use of byproducts in ruminant diets may positively affect these factors by creating a

Received June 22, 2011.

Accepted October 10, 2011.

${ }^{1}$ Corresponding author: sabrina.greenwood@lincoln.ac.nz use for the waste products of other industries and by providing dietary compounds to alter ruminant outputs (excrement and milk). Several byproducts arise from the viticulture industry, such as marc, lees, vine shoot trimmings, and vine prunings (Nerantzis and Tataridis. 2006). These products are being fed on commercial dairy farms in New Zealand, but the metabolic effects of dietary inclusion of these byproducts are relatively unknown. Grape marc and lees contain moderate levels $(18-200 \mathrm{~g} / \mathrm{kg}$ of DM) of condensed tannins (CT; Molina-Alcaide et al., 2008), which can bind proteins and make the proteins unavailable for ruminal degradation and absorption (Barry and McNabb, 1999; Waghorn, 2008). This dietary supplement could be useful in situations in which the ruminant is receiving excess dietary protein, such as in the New Zealand dairy industry, which relies heavily on a ryegrass-clover pasture high in CP (Bryant et al., 2010). Use of CT-containing plant species in pastures has been documented as one strategy to decrease the proportion of urinary $\mathrm{N}$ relative to fecal N (urine:fecal N ratio; Waghorn et al., 1987; Powell et al., 2009; Woodward et al., 2009). Decreasing the urine:fecal $\mathrm{N}$ ratio is desirable from an environmental perspective. Approximately 70 to $90 \%$ of ingested N is excreted in urine and feces, resulting in up to 1,000 $\mathrm{kg}$ of urinary $\mathrm{N} / \mathrm{ha}$ being excreted onto pastures, and approximately $23 \%$ of this urinary $\mathrm{N}$ then contaminating ground water as nitrate leaching (Di and Cameron, 2007). The objective was to examine if use of grape marc as a supplement to pasture-based dairy diets can decrease urinary $\mathrm{N}$ excretion.

All procedures were approved by the Lincoln University Animal Ethics Committee. Eighteen multiparous nonlactating Friesian $\times$ Jersey crossbred dairy cows were maintained at the Lincoln University Research Dairy Farm (Lincoln University, Lincoln, New Zealand). Cows of similar body condition were selected $(3.9 \pm 0.3$, BCS scale of 1 to 10; Roche et al., 2009). Cows were blocked by daily milk solids (milk protein + fat yield) production during the previous lactation $(1.75 \pm 0.23 \mathrm{~kg}$ of milk solids/d), age $(5.2 \pm 1.7 \mathrm{yr})$, and BW (498. $\pm 55.1 \mathrm{~kg})$, and randomly assigned to 1 of 2 treatments, with the experiment being performed 
during May 2010. Groups were randomly designated each to one pasture area within the same plot to ensure that pasture composition, previous grazing scheme, and irrigation scheme were similar across both areas used for grazing. In addition, pasture samples were collected and analyzed as described below to verify that both grazing areas were of similar botanical composition and nutritive quality. The 2 treatment groups were grazed separately and both groups received ad libitum access to a perennial ryegrass-white clover pasture and water throughout the baseline period and experiment. All cows were offered an increasing amount of a commercially available dairy energy pellet (Dairy Elite $12 \%$, Weston Milling, Christchurch, New Zealand) from d 1 to 5 (increased by $20 \%$ of maximum target/d) to stimulate eating in the individual feeding area, and were maintained on their maximum daily pellet offering of $2 \mathrm{~kg}$ of $\mathrm{DM} / \mathrm{d}$ from d 5 to 9 . In addition to receiving the pellet, treatment cows $(\mathrm{n}=9)$ received an increasing amount of grape marc (50\% wet weight of white and $50 \%$ red grape marc; Pernod Ricard NZ Ltd., Brancott Winery, Blenheim, New Zealand) from d 1 to 5 (increase by $20 \%$ of maximum target/d) and were maintained on their maximum daily grape marc offering of $3 \mathrm{~kg}$ of DM/d from d 5 to 9 . The entire allowance of supplement, including energy pellet (control group) or energy pellet + grape marc, was offered at $1400 \mathrm{~h}$ daily in feed troughs. For this reason, individual cow intake of supplement could not be determined. Treatment groups were offered new grazing areas daily after receiving their supplement. Pasture intakes of the 2 treatment groups were estimated daily by determination of pasture pre- and post- grazing mass using a rising plate meter (Filips Folding Plate Meter, Jenquip, Feilding, New Zealand) as described previously (Bryant et al., 2010), which estimated pasture yield (kg of $\mathrm{DM} / \mathrm{ha}$ ) based on a regression equation. To create the regression equation in which the rising plate meter measurements were used to determine pasture mass, 5 pre- and 5 postgrazing pasture samples of known area were each cut at random twice during the experimental period from each treatment paddock. These samples were dried at $80^{\circ} \mathrm{C}$ until a constant weight was achieved, and $\mathrm{DM}$ content $(\mathrm{kg}$ of $\mathrm{DM} / \mathrm{ha}$ ) was determined. The difference between pasture pre- and postgrazing DM content was calculated for the measured pasture area to estimate pasture DMI and divided by the number of animals grazing ( $\mathrm{n}=9 /$ treatment). Pasture composition was determined by near-infrared spectroscopy (Feed and Forage Analyzer, Foss Analytical, Hillerød, Denmark), whereas grape marc chemical composition was determined by chemical methods. Briefly, the Van Soest method was used to determine NDF concentration (AOAC, 1990). Total $\mathrm{N}$ of grape marc was determined using a Variomax CN Analyzer (Vario MAX CN, Elementar Analysensysteme, Hanau, Germany), and total sugar content was determined using the anthrone reaction, based on Jermyn (1956) and Pollock and Jones (1979). Crude fat content was measured as total lipids by the Soxhlet Extraction in hexane using a Tecator Soxtec 1043 analyzer (Foss Analytical). Dry matter content of grape marc was determined gravimetrically, whereby samples were placed in a fan-forced oven at $100^{\circ} \mathrm{C}$ until a constant weight was achieved, and $\mathrm{OM}$ was determined by subsequent ashing of product using a muffle furnace at $550^{\circ} \mathrm{C}$ for $4 \mathrm{~h}$ (McLeod and Minson, 1978). Concentrations of $\mathrm{CT}$ in individual white and red grape marc samples were determined in duplicate using the methylcellulose precipitable method, where CT were extracted with an ethanol solution, and concentration was determined relative to an epicatechin standard after addition of a methylcellulose solution (Mercurio et al., 2007).

Blood, urine, and fecal samples were collected from all cows on d 0 and 9 beginning at $0900 \mathrm{~h}$. Blood samples $(10 \mathrm{~mL})$ were collected from the coccygeal vessel in EDTA-coated Vacuettes (Greiner Bio-One, Kremsmünster, Austria) and immediately placed on ice after collection. Samples were centrifuged at 3,000 $\times g$ for $15 \mathrm{~min}$ at $4^{\circ} \mathrm{C}$, and plasma was collected. Urine (approximately $60 \mathrm{~mL}$ ) was collected mid-stream during voluntary urination or during urination after manual stimulation by rubbing the vulva. Urine samples were acidified to a $\mathrm{pH}$ of approximately 4.0 using sulfuric acid immediately after collection. Fecal samples (approximately $200 \mathrm{~mL} ; 200 \mathrm{~g}$ ) were collected after rectal stimulation to induce defecation or during voluntary defecation. Plasma, urine, and feces samples were stored at $-20^{\circ} \mathrm{C}$ until analysis. All analyses were completed by Lincoln University Analytical Services (Lincoln University, Christchurch, New Zealand). Fecal samples were thawed and a subsample was weighed to conduct laboratory analysis, dried in an oven at $65^{\circ} \mathrm{C}$ for 48 $\mathrm{h}$, and reweighed to calculate DM percentage of feces. A second subsample of feces was freeze-dried, ground to $1 \mathrm{~mm}$, and analyzed for $\mathrm{N}$ percentage (Vario MAX $\mathrm{CN}$, Elementar Analysensysteme). Urine samples were thawed, and subsamples used to determine percentage N, urea, and ammonia (Vario MAX CN, Elementar Analysensysteme). Urine creatinine concentration was determined using the Jaffé method (Bartels and Böhmer, 1971; Cobas Mira Plus Analyzer, Roche Hitachi, Basel, Switzerland). To estimate urinary N output (g/d), urine creatinine concentration, BW, and urinary percentage $\mathrm{N}$ (as $\mathrm{g} / \mathrm{kg}$ of urine) were included in the following calculation outlined by Pacheco et al. (2009): urinary $\mathrm{N}(\mathrm{g} / \mathrm{d})=21.9(\mathrm{mg} / \mathrm{kg}) \times \mathrm{BW}(\mathrm{kg}) \times[1 /$ urinary creatinine $(\mathrm{mg} / \mathrm{kg})] \times$ urine $\mathrm{N}(\mathrm{g} / \mathrm{kg})$. 
Results were analyzed using PROC MIXED (SAS Inst. Inc., Cary, NC). The statistical model was $\mathrm{Y}_{\mathrm{ij}}=$ $\mu+\alpha_{i}+\beta_{j}+\varepsilon_{i j}$, where $Y_{i j}$ was the dependent variable, $\mu$ was the overall mean, $\alpha_{i}$ was the effect of treatment, $\beta_{j}$ was the effect of block (blocked by average milk solids production of previous lactation, age, and $\mathrm{BW})$, and $\varepsilon_{\mathrm{ij}}$ was the random residual error. Day 0 measurements were included as a covariate for statistical analyses of plasma, urine, and fecal results. Individual cow plasma, fecal, and urine results were statistically analyzed, whereas total DMI and dietary $\mathrm{N}$ intake were estimated per treatment group using measured pasture intakes for each group and supplement (both energy pellet and grape marc) offered intakes per cow during the maximum supplement period (d 5 to 9). Block was nonsignificant $(P>0.05)$ and was removed from the model. Results were significant at $P<0.05$ unless stated otherwise.

Percentage of dietary inclusion of pasture (150 g of $\mathrm{DM} / \mathrm{kg} ; 232 \mathrm{~g}$ of $\mathrm{CP} / \mathrm{kg}$ of $\mathrm{DM} ; 2,937.8$ cal of $\mathrm{ME} /$ $\mathrm{kg}$ of DM), energy pellet (as per manufacturer label: $125 \mathrm{~g}$ of $\mathrm{CP} / \mathrm{kg}$ of $\mathrm{DM} ; 2,866.2$ cal of $\mathrm{ME} / \mathrm{kg}$ of $\mathrm{DM}$ ), and grape marc $(340 \mathrm{~g}$ of DM/kg; $130 \mathrm{~g}$ of $\mathrm{CP} / \mathrm{kg}$ of DM; $1,815.2$ cal of $\mathrm{ME} / \mathrm{kg}$ of $\mathrm{DM})$, as well as chemical composition of group estimated diets, are given in Table 1. Based on total dietary CP content (Table 1) and average DMI of treatment groups (Table 2), the control and grape marc groups had $\mathrm{N}$ intakes of 398.9 and $476.1 \mathrm{~g}$ of $\mathrm{N} / \mathrm{d}$, respectively $(P=0.18)$. Using the equation by Pacheco et al. (2009), urinary $\mathrm{N}$ output $(\mathrm{g} / \mathrm{d})$ from cows receiving grape marc was calculated as $192.6 \mathrm{~g}$ of $\mathrm{N} / \mathrm{d}$, and urinary $\mathrm{N}$ output from cows receiving the control diet was calculated as $216.0 \mathrm{~g}$ of $\mathrm{N} / \mathrm{d}(P=0.22)$. Cows receiving grape marc excreted

Table 1. Chemical composition of diets during experimental period ${ }^{1}$

\begin{tabular}{lrr}
\hline Item & $\begin{array}{c}\text { Control } \\
(\mathrm{n}=9)\end{array}$ & $\begin{array}{c}\text { Grape marc } \\
(\mathrm{n}=9)\end{array}$ \\
\hline Ingredient (\% of DM) & & \\
Perennial ryegrass-white clover pasture & 83.6 & 69.3 \\
Energy pellet & 16.4 & 13.5 \\
Grape marc & 0 & 17.2 \\
DM (\%) & 27.5 & 28.7 \\
Chemical composition & 21.5 & 20.1 \\
CP (\%; N $\times 6.25)$ & 34.5 & 35.3 \\
NDF (\%) & 1.3 & 9.0 \\
Condensed tannin ${ }^{2}(\mathrm{~g} / \mathrm{kg}$ of $\mathrm{DM})$ & $2,937.8$ & $2,722.8$ \\
ME (cal/kg of DM) &
\end{tabular}

${ }^{1}$ Animals received either ad libitum access to a perennial ryegrasswhite clover pasture supplemented with $2 \mathrm{~kg}$ of DM/d energy pellet offered daily (control) or ad libitum access to a perennial ryegrass-white clover pasture supplemented with an energy pellet $(2 \mathrm{~kg}$ of DM/d) and grape marc (3 kg of DM/d) offered daily (grape marc)

${ }^{2}$ Condensed tannin (CT) calculated using CT concentrations of 1.3, 0.0 , and $45.8 \mathrm{~g} / \mathrm{kg}$ of DM for perennial ryegrass-white clover pasture, energy pellet, and grape marc, respectively. Pasture CT concentrations from Ramirez-Restrepo and Barry (2005); grape marc CT concentrations determined in current experiment.
$22 \%$ more $\mathrm{N}$ in feces compared with the control group $(P<0.0001)$. In terms of $\mathrm{N}(\mathrm{g} / \mathrm{d})$ excreted in urine as a proportion of $\mathrm{N}(\mathrm{g} / \mathrm{d})$ intake, the control group partitioned $54 \%$ of their $\mathrm{N}$ intake into urine, whereas the cows fed grape marc partitioned $41 \%$ of ingested $\mathrm{N}$ into urine. In addition, cows receiving grape marc excreted less urinary ammonia $(P=0.0073)$. Although no significant difference in urine urea concentrations was observed between the grape marc and control cows (84.3 vs. $114.11 \mathrm{mmol} / \mathrm{L}$, respectively; $P=0.26$ ), cows receiving grape marc had lower concentrations of plasma urea nitrogen $(P=0.009)$ compared with the control group.

The CT content of grape marc was $45.8 \mathrm{~g} / \mathrm{kg}$ of DM, and total CT concentration of the control and grape marc diets was 1.3 and $9.0 \mathrm{~g} / \mathrm{kg}$ of DM, respectively (Table 1). Inclusion of CT in dairy cattle diets as low as $6.5 \mathrm{~g} / \mathrm{kg}$ of $\mathrm{DM}$ decreased the urine:feces $\mathrm{N}$ ratio (Woodward et al., 2009). In addition, decreased CP digestibility of grape marc was abolished with the addition of polyethylene glycol, with no observed changes in intestinal digestibility (Molina-Alcaide et al., 2008). It should be noted that the grape varieties used in the current study had lower CT concentrations than those in the previous study, which determined total CT as 90.5 and $202.6 \mathrm{~g} / \mathrm{kg}$ of DM in grape marc obtained from 2 different distilleries. Any suggestion that the beneficial effect of grape marc on $\mathrm{N}$ digestibility or partitioning is solely attributed to CT must be made with caution. Other bioactive compounds within grape marc could also contribute to the changes in $\mathrm{N}$ parameters observed in the current study.

Feeding grape marc to nonlactating dairy cattle appears to have reduced $\mathrm{N}$ digestibility based on the higher fecal $\mathrm{N}$ of cows fed grape marc compared with cows fed the control diet. This may be particularly beneficial when feeding diets high in rumen-degradable protein such as in a ryegrass-clover pasture, creating a greater partitioning of $\mathrm{N}$ toward feces instead of absorption (Bryant et al., 2010). Further study would be beneficial to elucidate the dynamics of these $\mathrm{N}$ measures relative to offering the supplement using total fecal collection, because the current study only determined measures at a single sampling point on d 9 and did not measure fecal $\mathrm{N} / \mathrm{d}$ to establish the absolute urine:fecal $\mathrm{N}$ ratio. In addition, further research must be conducted to identify whether CT are the primary cause of these effects, or whether other chemical properties of grape marc induce changes in $\mathrm{N}$ partitioning of the dairy cow.

\section{ACKNOWLEDGMENTS}

The authors thank Lincoln University employees V. Walpot and J. Leal for assistance during the experimen- 
Table 2. Nitrogen measures of diet, plasma, urine, and feces ${ }^{1}$

\begin{tabular}{|c|c|c|c|c|}
\hline Item & $\begin{array}{l}\text { Control } \\
(\mathrm{n}=9)\end{array}$ & $\begin{array}{l}\text { Grape marc } \\
\quad(\mathrm{n}=9)\end{array}$ & SEM & $P$-value \\
\hline $\mathrm{DMI}^{2}(\mathrm{~kg} / \mathrm{d})$ & 11.6 & 14.8 & 1.09 & \\
\hline $\mathrm{N}$ dietary intake ${ }^{2}(\mathrm{~g} / \mathrm{d})$ & 398.9 & 476.1 & 36.36 & \\
\hline \multicolumn{5}{|l|}{ Urine $^{3}$} \\
\hline Nitrogen (\%) & 0.42 & 0.32 & 0.066 & 0.31 \\
\hline Creatinine $(\mu \mathrm{mol} / \mathrm{L})$ & $1,854.1$ & $1,632.4$ & 311.1 & 0.63 \\
\hline $\mathrm{N}$ output $(\mathrm{g} / \mathrm{d})$ & 216.0 & 192.6 & 12.84 & 0.22 \\
\hline Ammonia $(\mathrm{mmol} / \mathrm{L})$ & 1.18 & 0.58 & 0.14 & 0.0073 \\
\hline Urea $(\mathrm{mmol} / \mathrm{L})$ & 114.1 & 84.24 & 17.62 & 0.26 \\
\hline \multicolumn{5}{|l|}{ Feces $^{3}$} \\
\hline $\mathrm{N}(\%)$ & 2.12 & 2.71 & 0.066 & $<0.0001$ \\
\hline $\mathrm{DM}(\%)$ & 16.15 & 18.01 & 1.22 & 0.31 \\
\hline \multicolumn{5}{|l|}{ Plasma $^{3}$} \\
\hline Urea $(\mathrm{mmol} / \mathrm{L})$ & 2.97 & 2.42 & 0.10 & 0.009 \\
\hline
\end{tabular}

${ }^{1}$ Animals received either ad libitum access to a perennial ryegrass-white clover pasture supplemented with 2 $\mathrm{kg}$ of DM/d energy pellet offered daily (control treatment) or ad libitum access to a perennial ryegrass-white clover pasture supplemented with an energy pellet $(2 \mathrm{~kg}$ of DM/d) and grape marc $(3 \mathrm{~kg}$ of DM/d) offered daily (grape marc treatment)

${ }^{2} \mathrm{DMI}$ and $\mathrm{N}$ dietary intake $(\mathrm{g} / \mathrm{d})$ both estimated based on group intake of treatment group.

${ }^{3}$ Urine, feces, and plasma measures determined on each sample collected from individual cows.

tal phase, and R. Hider (Lincoln University, Lincoln, New Zealand) for conducting laboratory analysis to determine CT concentration of grape marc. The authors also thank Pernod Ricard (NZ Ltd., Brancott Winery, Blenheim, New Zealand) for donating the grape marc used in the current study. Funding provided by the Lincoln University Research Fund (LURF) is gratefully acknowledged.

\section{REFERENCES}

AOAC. 1990. Official Methods of Analysis. 15th ed. AOAC, Gaithersburg, MD.

Barry, T. N., and W. C. McNabb. 1999. The implications of condensed tannins on the nutritive value of temperate forages fed to ruminants. Br. J. Nutr. 81:263-272.

Bartels, H., and M. Böhmer. 1971. Micro-determination of creatinine. Clin. Chim. Acta 32:81-85.

Bryant, R. H., V. Walpot, D. E. Dalley, S. J. Gibbs, and G. R. Edwards. 2010. Manipulating dietary $\mathrm{N}$ in perennial ryegrass pastures to reduce $\mathrm{N}$ losses in dairy cows in spring. Pages $97-100$ in Proc. Australasian Dairy Sci. Symp., Lincoln, New Zealand. Lincoln University, Lincoln, New Zealand.

Di, H. J., and K. C. Cameron. 2007. Nitrate leaching losses and pasture yields as affected by different rates of animal urine nitrogen returns and application of a nitrification inhibitor-A lysimeter study. Nutr. Cycl. Agroecosyst. 79:281-290.

Jermyn, M. A. 1956. A new method for the determination of ketohexoses in the presence of aldohexoses. Nature 177:38-39.

McLeod, M. N., and D. J. Minson. 1978. The accuracy of the pepsincellulase technique for estimating the dry matter digestibility in vivo of grasses and legumes. Anim. Feed Sci. Technol. 3:277-287.

Mercurio, M. D., R. G. Dambergs, M. J. Herderich, and P. A. Smith. 2007. High throughput analysis of red wine and grape phenolics-
Adaptation and validation of methyl cellulose precipitable tannin assay and modified Somers color assay to a rapid 96 well plate format. J. Agric. Food Chem. 55:4651-4657.

Molina-Alcaide, E., A. Moumen, and A. I. Martín-García. 2008. Byproducts from viticulture and the wine industry: Potential as sources of nutrients for ruminants. J. Sci. Food Agric. 88:597-604.

Nerantzis, E. T., and P. Tataridis. 2006. Integrated enology-Utilization of winery by-products into high added value products. J. Food Sci. Technol. 3:1-12.

Pacheco, D., K. Lowe, J. L. Burke, and G. P. Cosgrove. 2009. Urinary nitrogen excretion from cows at different stage of lactation grazing different ryegrass cultivars during spring or autumn. Proc. N.Z. Soc. Anim. Prod. 69:196-200.

Pollock, C. J., and T. Jones. 1979. Seasonal patterns of fructan metabolism in forage grasses. New Phytol. 83:9-15.

Powell, J. M., G. A. Broderick, J. H. Grabber, and U. C. Hymes-Fecht. 2009. Technical note: Effects of forage protein-binding polyphenols on chemistry of dairy excreta. J. Dairy Sci. 92:1765-1769.

Ramirez-Restrepo, C. A., and T. N. Barry. 2005. Alternative temperate forages containing secondary compounds for improving sustainable productivity in grazing ruminants. Anim. Feed Sci. Technol. 120:179-201.

Roche, J. R., N. C. Friggens, J. K. Kay, M. W. Fisher, K. J. Stafford, and D. P. Berry. 2009. Invited review: Body condition score and its association with dairy cow productivity, health, and welfare. J. Dairy Sci. 92:5769-5801.

Waghorn, G. 2008. Beneficial and detrimental effects of dietary condensed tannins for sustainable sheep and goat production-Progress and challenges. Anim. Feed Sci. Technol. 147:116-139.

Waghorn, G. C., M. J. Ulyatt, A. John, and M. T. Fisher. 1987. The effect of condensed tannins on the site of digestion of amino acids and other nutrients in sheep fed on Lotus corniculatus L. Br. J. Nutr. 57:115-126.

Woodward, S. L., G. C. Waghorn, K. A. Watkins, and M. A. Bryant. 2009. Feeding birdsfoot trefoil (Lotus corniculatus) reduces the environmental impacts of dairy farming. Proc. N.Z. Soc. Anim. Prod. 69:179-183. 